\title{
Gamna-Gandy bodies in hepatosplenic schistosomiasis mansoni
}

Corpos de Gamna-Gandy na esquistossomose mansônica hepatoesplênica

José Roberto Lambertucci ${ }^{1}$, Izabela Voieta ${ }^{1}$ and Luciene Mota Andrade ${ }^{2}$

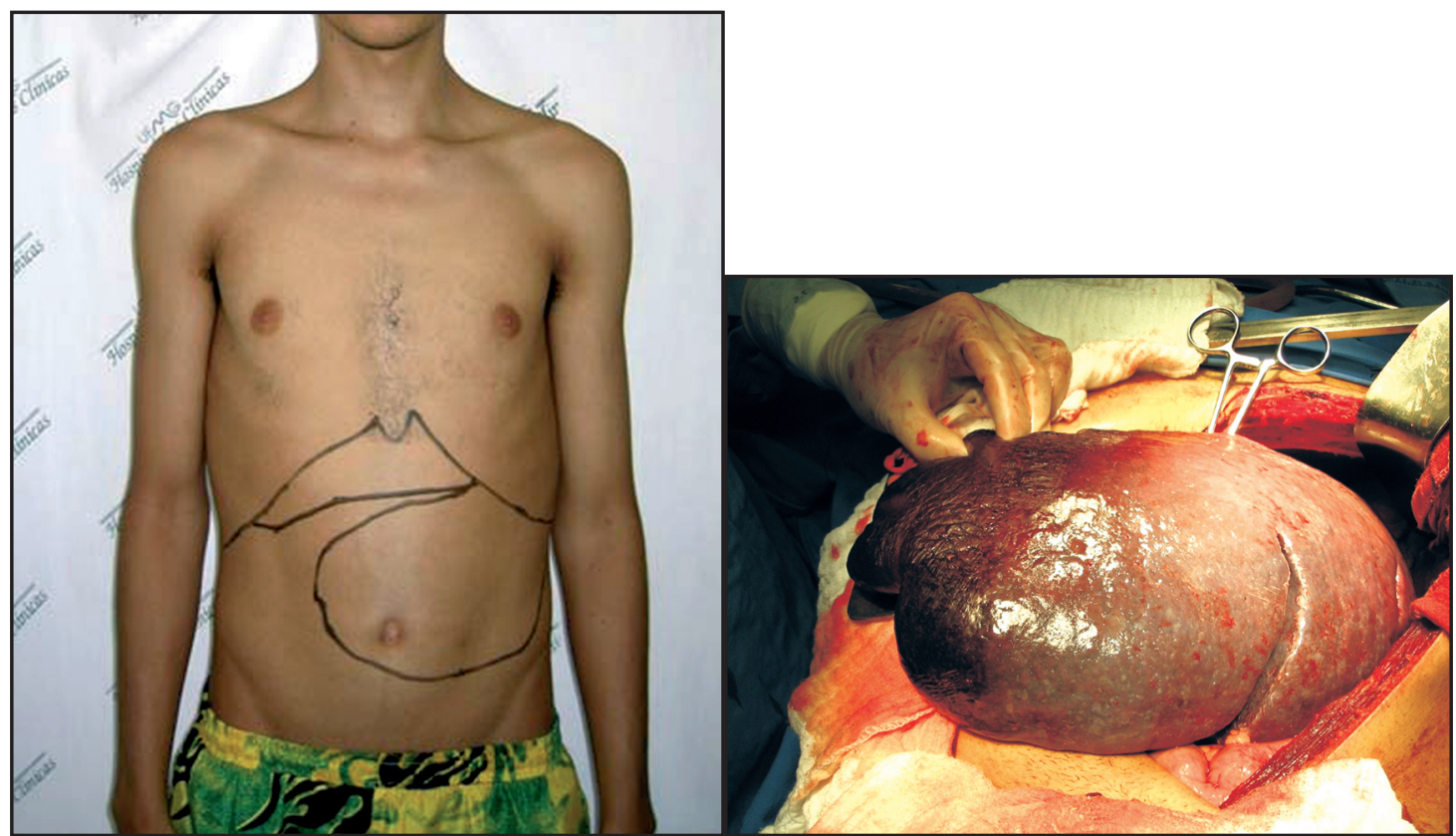

A

B

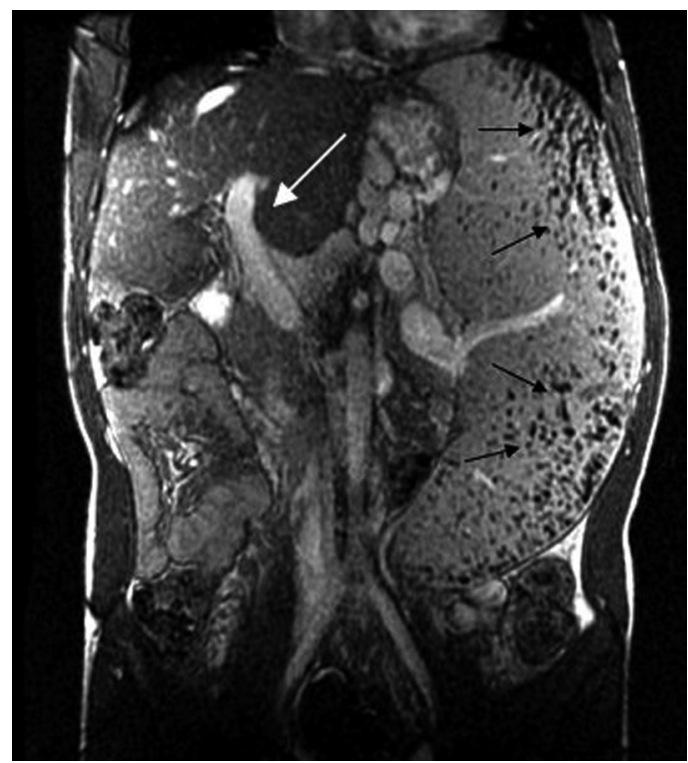

C

1. Curso de Pós-Gradução em Ciências da Saúde: Infectologia e Medicina Tropical, Faculdade de Medicina, Universidade Federal de Minas Gerais, Belo Horizonte, MG. 2. Laboratório Hermes Pardini, Belo Horizonte, MG.

Address to: Prof. José Roberto Lambertucci. Faculdade de Medicina/UFMG. Avenida Alfredo Balena 190, 30130-100 Belo Horizonte, MG, Brasil. email: lamber@uai.com.br

Recebido para publicação em: 25/04/2008

Aceito em: 02/05/2008 
A 24-year-old male patient with a diagnosis of hepatosplenic schistosomiasis mansoni was admitted to hospital with a history of upper digestive bleeding, pancytopenia and a huge spleen (Figures $\mathrm{A}$ and $\mathrm{B}$ ). Magnetic resonance imaging (Figure $\mathrm{C}$ ) in a $\mathrm{T} 2$ weighted image in the coronal plane (FIESTA), showed splenomegaly and Gamna-Gandy bodies (black arrows) that appeared as foci of low signal intensity or signal void. The portal vein was seen to be patent (white arrow). After a series of tests, he underwent an operation to treat portal hypertension (splenectomy, portal-variceal disconnection and suturing of the esophageal varices). Thirty days after discharge from hospital, he was reexamined at the outpatient clinic and was found to be asymptomatic. Gamna-Gandy bodies (siderotic nodules) consist of organized foci of bleeding within the spleen caused by portal hypertension. These lesions contain fibrous tissue, hemosiderin and calcium. They are also found in cases of portal or splenic thrombosis, hemolytic anemia, leukemia or lymphoma, acquired hemochromatosis and paroxysmal nocturnal hemoglobinuria, and in cases with blood transfusion.

O paciente, de 24 anos, tinha o diagnóstico de esquistossomose mansônica hepatoesplênica e foi admitido ao hospital com história de hemorragia digestiva alta, pancitopenia e baço enorme (Figuras A e B). A ressonância magnética (Figura C), na imagem ponderada em T2, em corte coronal (FIESTA), mostra esplenomegalia e nódulos de Gamna-Gandy (setas pretas) que aparecem como sinal de baixa intensidade ou vácuo; a veia porta é pérvia (seta branca). Depois de uma série de exames ele foi operado de hipertensão porta (esplenectomia, desconexão portavarizes e sutura de varizes do esôfago). Trinta dias após a alta hospitalar ele foi re-examinado em ambulatório e encontrava-se assintomático. Os nódulos de Gamna-Gandy (nódulos sideróticos) são focos hemorrágicos organizados dentro do baço causados pela hipertensão porta. Os nódulos contêm tecido fibroso, hemosiderina e cálcio. Eles também são encontrados em casos de trombose porta ou esplênica, anemia hemolítica, leucemia ou linfoma, hemocromatose adquirida, hemoglobinúria paroxística noturna e em transfusão de sangue.

\section{REFERENCES}

1. Lambertucci JR, Serufo JC, Gerspacher-Lara R, Rayes AA, Teixeira R, Nobre V, Antunes CM. Schistosoma mansoni: assessment of morbidity before and after control. Acta Tropica 77: 101-109, 2000.

2. Lambertucci JR, Silva LC, Andrade LM, Queiroz LC, Pinto-Silva RA. Magnetic resonance imaging and ultrasound in hepatosplenic schistosomiasis mansoni. Revista da Sociedade Brasileira de Medicina Tropical 37: 333-337, 2004.

3. Shweta B, Simon R, Dogra VS. Gamna-Gandy bodies: sonographic features with histopathologic correlation. Journal of Ultrasound in Medicine 25: 1625-1626, 2006 . 